\title{
Synthesis of thieno[2,3-b]benzo[1,8] naphthyridine-2-carboxylic acids under microwave irradiation and interaction with DNA studies
}

\author{
Tangali R. Ravikumar Naik, Halehatty S. Bhojya Naik*, M. Raghavendra and \\ Shankarahalli Gopal Krishna Naik \\ Department of P. G. Studies and Research in Industrial Chemistry, \\ School of Chemical Sciences, Kuvempu University, Shankaraghatta-577 451, India \\ E-mail: hsb_naik@rediffmail.com
}

\begin{abstract}
The microwave-enhanced synthesis of 2-chloro-3-formylbenzo[1,8]naphthyridines 3a-c has been achieved rapidly in good yield via the Vilsmeier-Haack cyclisation of $N$-(4-methylquinolin-2yl)acetamide 2a-d. The precursors $N$-(4-methylquinolin-2-yl)acetamide derivatives were effectively prepared in a single step from 2-aminoquinoline and acetic anhydride in presence of Amberlite-120A cation exchange catalyst under microwave irradiation. Condensation of 3a-d, with thioglycolic acid under microwave irradiation using anhydrous potassium carbonate as catalyst afforded thieno[2,3-b]benzo[1,8]naphthyridine-2-carboxylic acids (TBNCS) 4a-g. Elemental analysis, IR, ${ }^{1} \mathrm{H}$ NMR, and mass spectral studies were used to characterize these compounds. The interaction of thieno[2,3-b]benzo[1,8]naphthyridine-2-carboxylic acid (TBNC) (4a) with CT-DNA was studied by UV-Vis, viscosity as well as thermal denaturation methods. On binding to DNA, the absorption spectrum underwent bathochromic and hypochromic shifts. Binding parameters, determined from spectrophotometeric measurements indicated a binding constant of $1.8 \times 10^{6} \mathrm{M}^{-1}$. The thieno[2,3-b]benzo[1,8]naphthyridine-2-carboxylic acid (4a) increases the viscosity of sonicated rod-like DNA fragments. The binding of TBNC to DNA increased the melting temperature by about $4^{0} \mathrm{C}$. DNA interaction studies suggest that (4a) binds to calf thymus DNA (CT-DNA).
\end{abstract}

Keywords: Microwave irradiation, naphthyridines, carboxylic acids, Amberlite-120A, DNA interaction

\section{Introduction}

Naphthyridine derivatives continued to be of great interest due to a wide spectrum of their biological activity. Antibiotics of this group are being widely used for the diagnostics and 
chemotherapy of infectious diseases of humans including AIDS. Some of new 1,8-naphthyridine derivatives including benzo[1,8]naphthyridine have recently been patented as growth regulators, fungicides, bactericides, herbicides, insecticides, and nemathocides of new generation, ${ }^{1-4}$ and they are also starting material for many naphthyridine derivatives.

Although many synthetic methods for the preparation of 1,8-naphthyridines have been reported, examination of literature reveals considerable scope for refinement of the existing procedures. Thus due to their great biological importance and employment of these compounds as starting material for the synthesis of various linearly tri and tetracyclic heterocycles of biological interest, the development of effective ways to synthesize these compounds utilizing inexpensive reagents continues to be an active area of research for synthetic organic chemists. ${ }^{5-10}$

There is evidence that antitumour activity is due to the intercalation between the base pairs of DNA and interference with normal functioning of the enzyme topoisomerase II which is involved in the breaking and releasing of DNA strands. ${ }^{14}$ Binding of these drugs is due to the presence of planar linearly fused tetracyclic heterocyclic system. This finding has stimulated the research in finding new antitumour drugs containing planar fused ring system. In recent years

various fused systems such as thiophene, ${ }^{15}$ furan and pyridine analogues of ellipticine ${ }^{16}$ and benzothiazoloquinolines ${ }^{17}$ have been studied for their properties. Recently, Cao and $\mathrm{He}^{15}$ studied DNA affinity properties of safranine- $T$ which features a planar phenazine ring and have shown that electrostatic binding plays an important role in the intercalation of safranine-T. The results of these various binding studies have been useful in designing new and promising anticancer agents for clinical use. ${ }^{18-20}$

To best of our knowledge there are no reports on the synthesis of benzo[1,8]naphthyridine under microwave irradiation by using inexpensive $N$-(4-methylquinolin-2-yl)acetamide as starting material. Hence, in search of an efficient method and in continuation of our work on microwave assisted organic synthesis of condensed heterocycles, ${ }^{21-23}$ we have investigated a new, simple, enviro-friendly method for the preparation of benzo[1,8]naphthyridines under microwave irradiation and also reported the interaction of newly synthesized TBNC (4a) with CT-DNA.

\section{Results and Discussion}

\section{Chemistry}

The required key intermediate $N$-(4-methylquinolin-2-yl)acetamide has been synthesized by the reaction of 2-amino-4-methylquinoline and acetic anhydride in the presence of Amberlite-120A catalyst in microwave irradiation (Scheme 1).

Vilsmeier-Haack reagent has been proved to be a versatile reagent capable of executing a large variety of synthetic transformation. It finds application in formylation, cyclohaloaddition, and cyclisation. The intramolecular cyclization potential of halomethyleniminium salts formed under the Vilsmeier condition and microwave-induced Vilsmeier conditions has been reported. ${ }^{24-}$ 
26 The classical Vilsmeier-Haack reaction involves electrophilic substitution of an activated aromatic ring with a halomethyleniminium salt to yield the corresponding imnium species, which facilitates its inclusion into a large number of novel heterocyclic systems.

Thus, the Vilsmeier-Haack reagent was used to cyclise $N$-(4-methylquinolin-2-yl) acetamide 2a-d carried out by adding $\mathrm{POCl}_{3}$ to the substrate in DMF. The reaction mixture was irradiated in microwave oven resulting in 2-chloro-3-formylbenzo[1.8]naphthyridines 3a-d with good yield of $90-95 \%$ in a short reaction time (Scheme 1). The structures of the new compounds were confirmed from the spectroscopic data and elemental analysis.

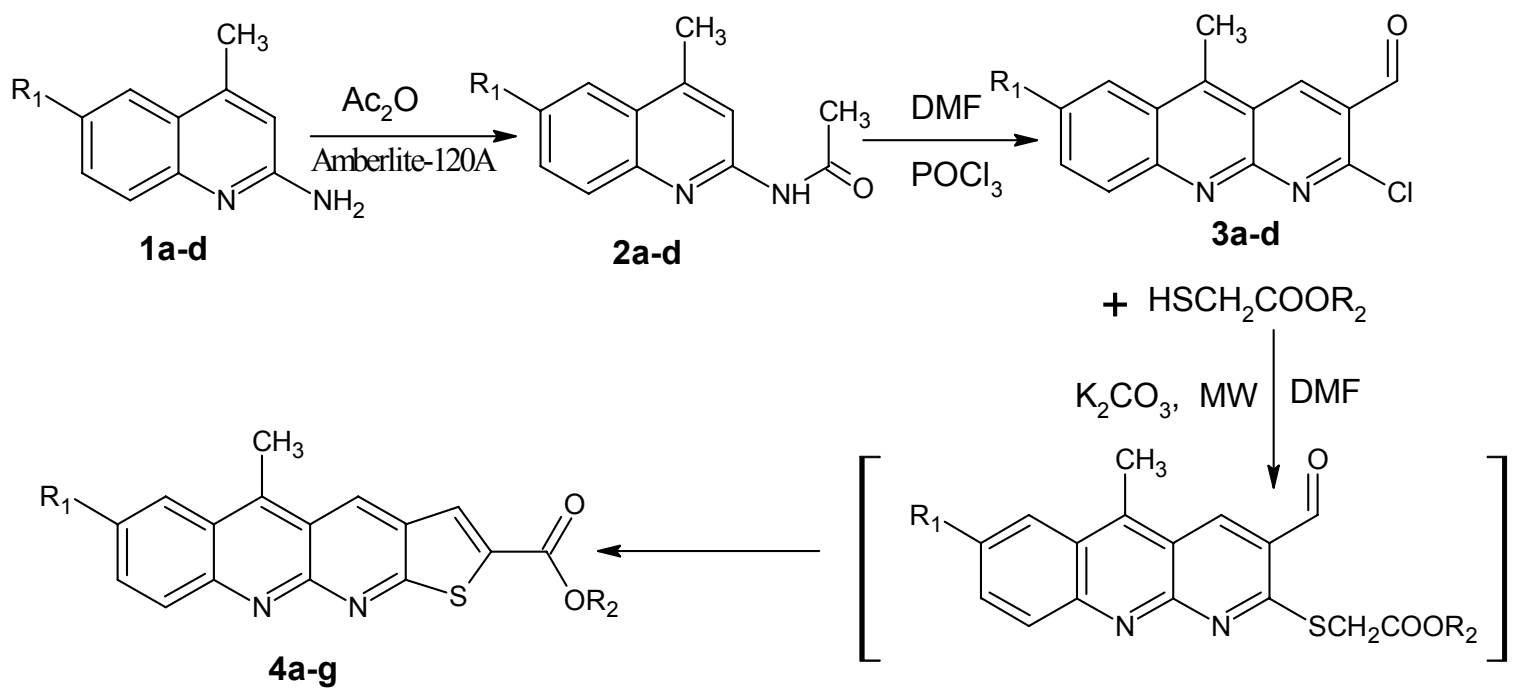

$$
\begin{gathered}
\mathbf{3 a}=\mathrm{R}_{1}=\mathrm{H}, \mathbf{3} \mathbf{b}=\mathrm{R}_{1}=\mathrm{CH}_{3}, \mathbf{3} \mathbf{c}=\mathrm{R}_{1}=\mathrm{OCH}_{3}, \mathbf{3 d}=\mathrm{R}_{1}=\mathrm{Br} \\
\mathbf{4 a}=\mathrm{R}_{1}=\mathrm{H}, \mathrm{R}_{2}=\mathrm{CH}_{3} \quad \mathbf{4 d}=\mathrm{R}_{1}=\mathrm{Br}, \mathrm{R}_{2}=\mathrm{C}_{2} \mathrm{H}_{5} \\
\mathbf{4} \mathbf{b}=\mathrm{R}_{1}=\mathrm{H}, \mathrm{R}_{2}=\mathrm{C}_{2} \mathrm{H}_{5} \quad \mathbf{4 e}=\mathrm{R}_{1}=\mathrm{CH}_{3}, \mathrm{R}_{2}=\mathrm{CH}_{3} \\
\mathbf{4} \mathbf{c}=\mathrm{R}_{1}=\mathrm{Br}, \mathrm{R}_{2}=\mathrm{CH}_{3} \quad \mathbf{4 f}=\mathrm{R}_{1}=\mathrm{CH}_{3}, \mathrm{R}_{2}=\mathrm{C}_{2} \mathrm{H}_{5} \\
\mathbf{4 g}=\mathrm{R}_{1}=\mathrm{OCH}_{3}, \mathrm{R}_{2}=\mathrm{C}_{2} \mathrm{H}_{5}
\end{gathered}
$$

Scheme 1. Synthesis of thieno[2,3-b]benzo[1,8]naphthyridine-2-carboxylic acids.

The starting compounds 2-chloro-3-formylbenzo[1.8]naphthyridines, were cyclised with thioglycolicacid/esters under microwave irradiation in one pot to furnish the title compounds (4a-g) in good yields (Scheme 1). The structures of the compounds were confirmed on the basis of elemental analysis and spectral data (Experimental section). As an example the IR ( $\mathrm{KBr}$ ) spectra of $4 \mathbf{b}$ exhibit an absorption band at $1678 \mathrm{~cm}^{-1}$ due to ester carbonyls and the ${ }^{1} \mathrm{H}$ NMR $\left(\right.$ DMSO- $\mathrm{d}_{6}$ ) spectrum of the compound $\mathbf{4 b}$ displayed a triplet at $\delta 1.37 \mathrm{ppm}(3 \mathrm{H})$ and a quatret at $\delta 4.37$ ppm $\left(\mathrm{CH}_{2}\right)$ characteristic of an ethyl group. Its mass spectrum showed the molecular ion peak at $324(\mathrm{M}+2)$. 
The reaction was proceeding through the formation of intermediate by the substitution of chlorine at $\mathrm{C}-2$ of $(\mathbf{3 a}-\mathbf{d})$ by the alkyl thioglycolates. In these intermediate the nucleophile generated by $\mathrm{K}_{2} \mathrm{CO}_{3}$ base knocks on the aldehyde carbon with simultaneous elimination of water offerded (4a-g) with good yields. We synthesized nine more title compounds, which exhibited similar spectral characteristics. The IR spectra of all the compounds exhibit $\mathrm{C}=\mathrm{O}$ stretching frequency in the region $1678-1700 \mathrm{~cm}^{-1}$. In the ${ }^{1} \mathrm{H}$ NMR thiophene $\mathrm{C} 3-\mathrm{H}$ proton showed a signal at $\delta 8.20-8.35 \mathrm{ppm}$, may be due to hydrogen bonding and anisotropy effect of the adjacent carbonyl groups and other aromatic protons resonated at $\delta 6.86-8.04 \mathrm{ppm}(\mathrm{m}, \mathrm{Ar}-\mathrm{H})$.

\section{DNA binding studies}

We studied the DNA binding properties of thieno[2,3- $b]$ benzo[1,8]naphthyridine-2-carboxylic acids (TBNC) (4a) which features planar fused tetracyclic heterocyclic rings. The planar hydrophobic moiety of TBNC is expected to facilitate into the relatively nonpolar interior of the DNA helix. The strong absorption, viscosity and thermal denaturation characteristics of TBNC drug provide a sensitive spectroscopic handle to study its interaction with DNA. The change in the intensities of these spectra can be used to decipher the nature and strength of the stacking interaction between the chromophore and the DNA base pairs.

The UV-Vis absorption spectrum of TBNC was characterized by two maxima at 460 and 520 $\mathrm{nm}$. The addition of increasingly higher concentrations of DNA led to bathochromic and hypochromic changes, as seen in Figure 1, i.e. the interaction of TBNC with DNA resulted in a strong decrease of the absorption intensity, accompanied by a shift towards higher wavelengths. A $21.8 \%$ reduction in absorption was observed at the $520 \mathrm{~nm}$ peak maximum in the presence of an excess of DNA at a molar ratio of DNA nucleotide: TBNC (P/D) equal to 15. Hypochromism was suggested to be due to strong interactions between the electronic states of the intercalating chromophore and that of the DNA base pairs. ${ }^{19}$ The spectral changes that we observed (hypochromicity and red shift) were consistent with the intercalation of the chromophore into the stack DNA base pairs ${ }^{27-31}$.

The change in the obsorbance values with increasing amount of CT-DNA were used to evaluate intrinsic binding constant $\mathrm{K}_{b}$, from the compounds the values of $\mathrm{K}_{b}$ are $1.8 \times 10^{6} \mathrm{M}^{-1}$. 


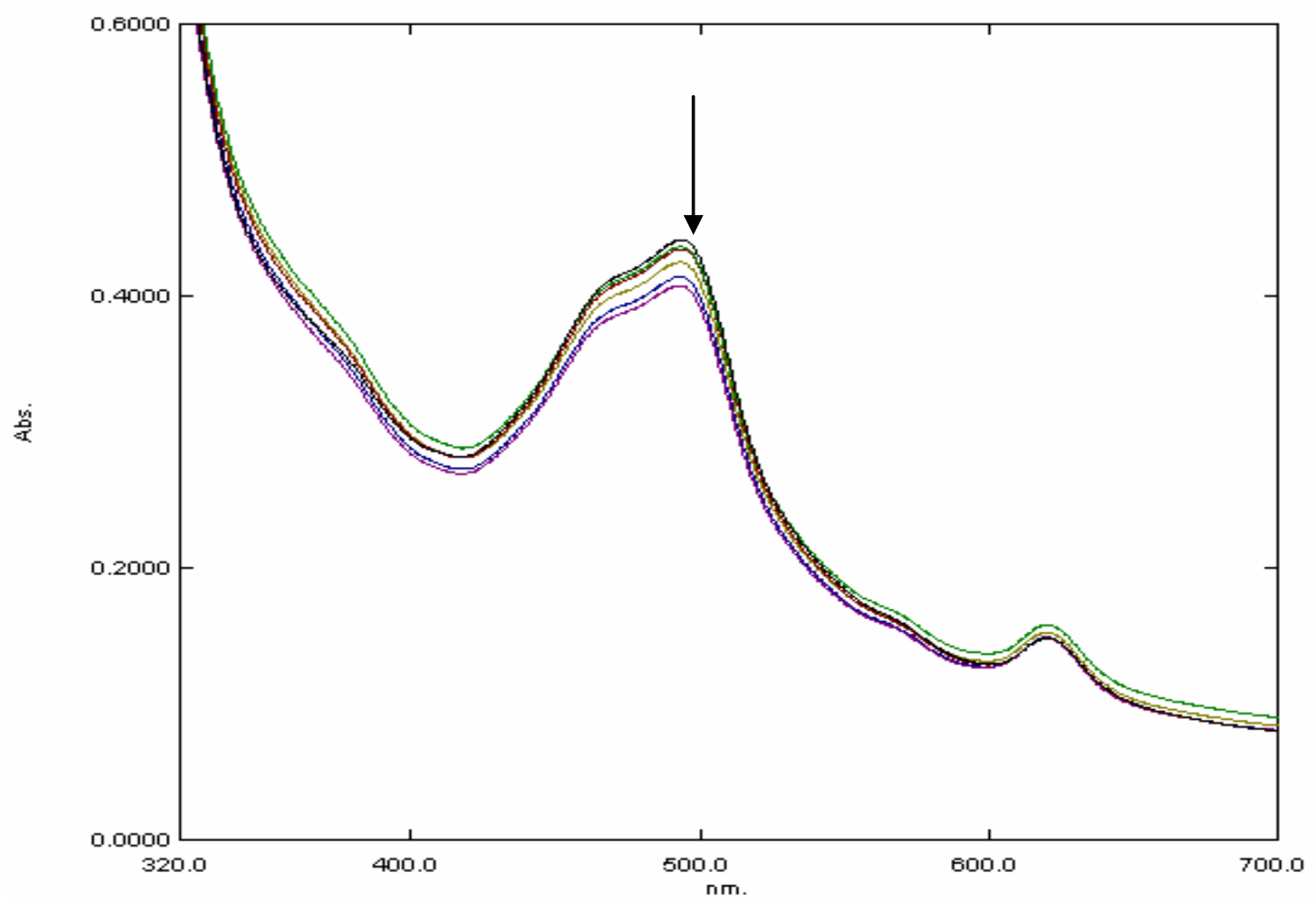

Figure 1. UV-absorption spectra of $\mathrm{TBNC}$ in Tris- $\mathrm{HCl}$ buffer upon addition of calf thymus DNA. [TBNC] $=0.5 \mu \mathrm{m},[\mathrm{DNA}]=10 \mu \mathrm{m}$ drug; $20 \mu \mathrm{m} ; 30 \mu \mathrm{m} ; 40 \mu \mathrm{m} ; 50 \mu \mathrm{m}$ DNA. Arrow shows the absorbance changing upon the increase of DNA concentration.

\section{Viscosity measurements}

An increase in viscosity of native DNA is regarded as a diagnostic feature of an intercalation process. ${ }^{32-35}$ We have measured the viscosity changes in short, rod like DNA fragments. The relative length increase $\left(\eta / \eta_{0}\right)$ of the complex formed between TBNC and

DNA is shown in Figure 2. It is evident that binding of TBNC increased the viscosity of DNA, corresponding to an increase in the contour length of the DNA fragments.

\section{Thermal denaturation measurements}

Other strong evidence for the binding of TBNC into the double helix DNA was obtained from DNA melting studies. The intercalation of small molecules into the double helix is known to increase the DNA melting temperature $\left(T_{m}\right)$, at which the double helix denatures into single stranded DNA, owing to the increased stability of the helix in the presence of an intercalator. ${ }^{36}$ The molar extinction coefficient of DNA bases at $260 \mathrm{~nm}$ in the double helical form is much less than the single stranded form; hence, melting of the helix leads to an increase in the absorbance at $260 \mathrm{~nm}$. Thus the helix to coil transition temperature can be determined by monitoring the absorbance of DNA at $260 \mathrm{~nm}$ as a function of temperature. The DNA melting studies were 
carried out with calf thymus DNA in the absence and presence of TBNC. The $T_{m}$ for calf thymus DNA with no TBNC present was $60^{\circ} \mathrm{C}$ and with TBNC a single transition at $68^{\circ} \mathrm{C}$ was observed (Figure 3). The advantage of this method is that it is much easier to identify when more than one transition occurs. ${ }^{37}$ These various DNA melting experiments strongly supported the intercalation of TBNC into the double helix DNA.

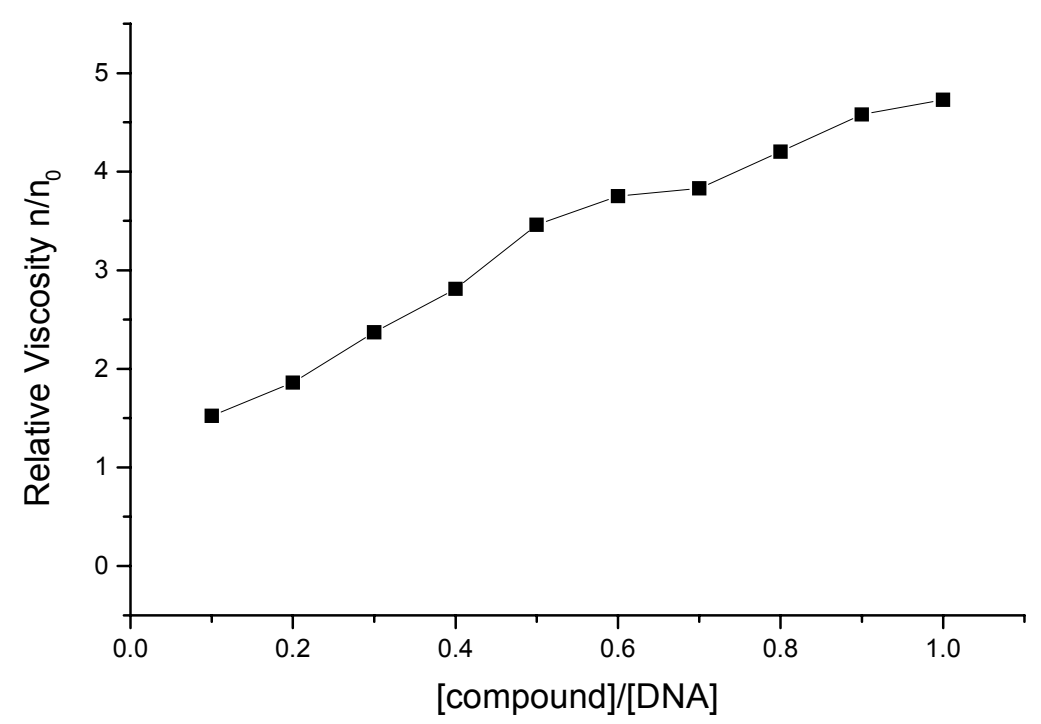

Figure 2. Effect of increasing amount of the TBNC (4a) on the relative viscosities of CT-DNA at $25{ }^{0} \mathrm{C}$

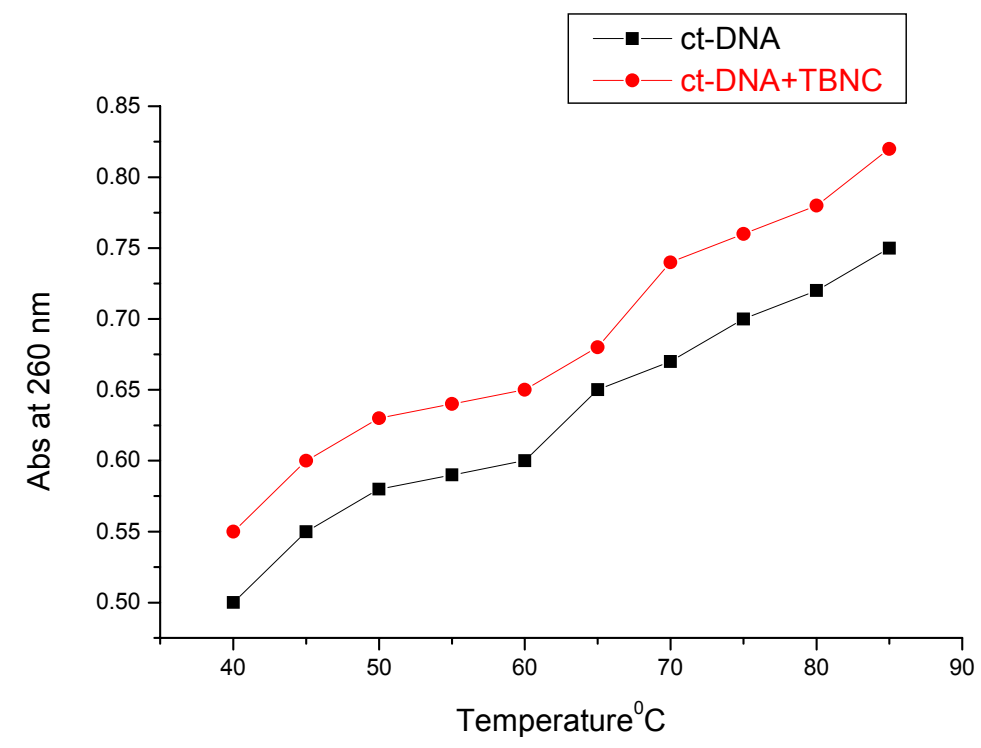

Figure 3. Melting cures of CT-DNA in the absence and presence of TBNC (4a). 


\section{Conclusions}

In conclusion, the presented synthetic procedure is convenient, simple and high yielding microwave-assisted method for the synthesis of benzo[1,8]naphthyridines using inexpensive 2aminoquinoline could be the economical method and more practical alternative to the existing methodologies. The study of binding behavior of structurally correlated tetracyclic thieno[2,3b]benzo[1,8]naphthyridine-2-carboxylic acid TBNC (4a) with (ds)DNA by use of absorption, viscosity and thermal denaturation studies. The results of all these studies provide coherent evidence that binding of TBNC with DNA. The absorption spectrum studies shows that, on binding of TBNC to DNA typical bathochromic and hypochromic shifts observed with a binding constant of $1.8 \times 10^{-6} \mathrm{M}^{-1}$, commonly reported for such drugs. The viscometric study shows that binding of TBNC increased the viscosity of ct-DNA. Thermal denaturation studies strongly supported the binding of ct-DNA by increased $T_{m}$ for ct-DNA about $8^{\circ} \mathrm{C}$ in presence of TBNC.

\section{Experimental Section}

General Procedures. Melting points were determined in an open capillary tube with a Buchi melting point apparatus and are uncorrected. Elemental analyses were carried out using PerkinElmer 240C CHN-analyzer. IR spectra were recorded on a FT-IR spectrophotometer. ${ }^{1} \mathrm{H}-\mathrm{NMR}$ spectra was run in (DMSO-d6) solvent at $300 \mathrm{MHz}$ and $75 \mathrm{MHz}$ on a NMR spectrophotometers (chemical shifts in $\delta \mathrm{ppm}$ ). Mass spectra were recorded on a LC MS Mass spectrometer. TLC monitored the reactions. The absorption spectral studies were carried out by Ultraviolet-visible spectrophotometer.

\section{General procedure for the synthesis of substituted benzo[1,8]naphthyridinones (3a-d)}

To a mixture of 2-amino-4-methylquinoline (5mmol), DMF (13mmol), $\mathrm{POCl}_{3}$ (45mmol) were added and the contents irradiated in MW at $160 \mathrm{~W}$ for 6 minutes. The completion of reaction was checked by TLC and poured in ice-cold water, the solid seperated was filted, dried, and recrystallized from acetonitrile 3a. The physicochemical data for the synthesized compounds are as shown below. The same procedure was used for the synthesis of other compounds (3b-d).

2-Chloro-5-methylbenzo[b]-1,8-naphthyridine-3-carbaldehyde (3a). Yellow solid. Yield 95 \%; mp. $149{ }^{0} \mathrm{C}$; FT-IR (KBr): 2960 (C-H), 1660 (C=O), ${ }^{1} \mathrm{H}$ NMR (DMSO-d $\left.6,300 \mathrm{MHz}\right): \delta$ $(\mathrm{ppm})=10.5(\mathrm{CHO}, \mathrm{s}), 7.02-8.03(\mathrm{~m}, \mathrm{Ar}-\mathrm{H}), 2.60(3 \mathrm{H}, \mathrm{s})$, Mass, m/z; $256(\mathrm{M}+2)$.Elemental analysis (\%): Calcd, for $\mathrm{C}_{14} \mathrm{H}_{9} \mathrm{ClN}_{2} \mathrm{O}$ : C; 65.51, H; 3.53, N; 10.91. Found: C; 65.50, H; 3.51, N; 10.89.

2-Chloro-5,7-dimethylbenzo[b]-1,8-naphthyridine-3-carbaldehyde (3b). Yellow solid. Yield $93 \%$; mp. $150{ }^{0} \mathrm{C}$; FT-IR (KBr): $2962(\mathrm{C}-\mathrm{H}), 1659$ (C=O), ${ }^{1} \mathrm{H}$ NMR (DMSO-d $\left.6,300 \mathrm{MHz}\right): \delta$ $(\mathrm{ppm})=10.5(\mathrm{CHO}, \mathrm{s}), 7.0-8.02(\mathrm{~m}, \mathrm{Ar}-\mathrm{H}), 8.20(3 \mathrm{H}, \mathrm{s}), 2.65(3 \mathrm{H}, \mathrm{s})$, Mass, m/z; $270(\mathrm{M}+2)$. 
Elemental analysis (\%): Calcd, for $\mathrm{C}_{15} \mathrm{H}_{11} \mathrm{ClN}_{2} \mathrm{O}: \mathrm{C} ; 66.55, \mathrm{H} ; 4.10, \mathrm{~N} ; 10.35$. Found: $\mathrm{C} ; 65.53$, $\mathrm{H} ; 4.08, \mathrm{~N} ; 10.33$.

2-Chloro-5,7-dimethylbenzo[b]-1,8-naphthyridine-3-carbaldehyde (3c). Yellow solid. Yield $93 \%$; mp. $160{ }^{0} \mathrm{C}$; FT-IR (KBr): $2958(\mathrm{C}-\mathrm{H}), 1680(\mathrm{C}=\mathrm{O}),{ }^{1} \mathrm{H}$ NMR (DMSO-d $\left.6,300 \mathrm{MHz}\right): \delta$ $(\mathrm{ppm})=10.5(\mathrm{CHO}, \mathrm{s}), 7.02-8.01(\mathrm{~m}, \mathrm{Ar}-\mathrm{H}), 8.22(3 \mathrm{H}, \mathrm{s}), 2.60(3 \mathrm{H}, \mathrm{s})$, Mass, m/z; $286(\mathrm{M}+2)$. Elemental analysis (\%): Calcd, for $\mathrm{C}_{15} \mathrm{H}_{11} \mathrm{ClN}_{2} \mathrm{O}$ : C; 62.84, H; 3.87, N; 9.77. Found: C; 62.82, H; $3.85, \mathrm{~N} ; 9.75$.

7-Bromo-2-chloro-5-methylbenzo[b]-1,8-naphthyridine-3-carbaldehyde (3d). Yellow solid. Yield $92 \%$; mp.165 ${ }^{0} \mathrm{C}$; FT-IR (KBr): 2964 (C-H), $1700(\mathrm{C}=\mathrm{O}),{ }^{1} \mathrm{H}$ NMR (DMSO-d 6,300 $\mathrm{MHz}): \delta(\mathrm{ppm})=10.5(\mathrm{CHO}, \mathrm{s}), 7.0-8.03(\mathrm{~m}, \mathrm{Ar}-\mathrm{H}), 2.60(3 \mathrm{H}, \mathrm{s})$, Mass, m/z; $335(\mathrm{M}+2)$. Elemental analysis (\%): Calcd, for $\mathrm{C}_{14} \mathrm{H}_{8} \mathrm{ClBrN}_{2} \mathrm{O}$ : C; 50.11, H; 2.40, N; 8.35. Found: C; 50.08, $\mathrm{H} ; 2.37, \mathrm{~N} ; 8.32$.

General procedure for the synthesis of substituted thieno[2,3-b]benzo[1,8] naphthyridines (TBNC) (4a-g)

A mixture of benzo [1.8] naphthyridine $(0.004 \mathrm{~mol})$, anhydrous thioglycolic ester $(0.005 \mathrm{~mol})$ and anhydrous potassium carbonate $(0.012 \mathrm{~mol})$ and anhydrous dimethylformamide $(10 \mathrm{ml})$ were added in a beaker, this mixture is irradiated in $\mathrm{MW}$ at $160 \mathrm{~W}$ for 7 minutes. The completion of reaction was check by TLC and poured in ice-cold water, the solid separated was filtered, dried, and recrystallized from ethanol: dioxane (6:4) 4a. The physicochemical data for the synthesized compounds are as shown below. The same procedure was used for the synthesis of other compounds (4b-g).

Methyl thieno[2,3-b]benzo[1,8]naphthyridine-2-carboxylate (4a). Yellow solid. Yield $80 \%$; mp. $235{ }^{0} \mathrm{C}$; FT-IR (KBr): $1650(\mathrm{C}=\mathrm{O}) \mathrm{cm}^{-1} .{ }^{1} \mathrm{H}$ NMR (DMSO-d $\left.6,300 \mathrm{MHz}\right): \delta(\mathrm{ppm})=3.90(\mathrm{~s}$, $\left.3 \mathrm{H},-\mathrm{O}-\mathrm{CH}_{3}\right), 6.86-8.03$ (m, 8H,Ar-H), 8.34 (s, 1H, H-3), Mass, m/z; $310(\mathrm{M}+2)$. Elemental analysis (\%): Calcd, for $\mathrm{C}_{17} \mathrm{H}_{12} \mathrm{~N}_{2} \mathrm{O}_{2} \mathrm{~S}$ : C; 66.22, H; 3.92, N; 9.08, S; 10.40 Found: C; 66.20, H; 3.90, N; 9.07,S; 10.37 .

Ethyl thieno[2,3-b]benzo[1,8]naphthyridine-2-carboxylate (4b). Yellow solid. Yield $85 \%$; mp.206 ${ }^{0} \mathrm{C}$; FT-IR (KBr): $1655(\mathrm{C}=\mathrm{O}) \mathrm{cm}^{-1} .{ }^{1} \mathrm{H}$ NMR (DMSO-d $\left.6,300 \mathrm{MHz}\right): \delta(\mathrm{ppm})=1.35(\mathrm{t}$, $\left.3 \mathrm{H},-\mathrm{CH}_{3}\right) 4.23\left(\mathrm{~d}, 2 \mathrm{H}-\mathrm{OCH}_{2}\right)$ 7.0-8.03 (m, 8H,Ar-H), 8.38 (s, 1H, 3-H,) Mass, m/z; 324 $(\mathrm{M}+2)$. Elemental analysis (\%): Calcd, for $\mathrm{C}_{18} \mathrm{H}_{14} \mathrm{~N}_{2} \mathrm{O}_{2} \mathrm{~S}: \mathrm{C} ; 67.06, \mathrm{H} ; 4.38, \mathrm{~N} ; 8.69$, S; 9.95 Found: C; 67.05, H; 4.35, N; 8.67,S; 9.93.

Methyl 6-bromothieno[2,3-b]benzo[1,8]naphthyridine-2-carboxylate (4c). Yellow solid. Yield $78 \%$; mp. $231{ }^{0} \mathrm{C}$; FT-IR $(\mathrm{KBr}): 1680(\mathrm{C}=\mathrm{O}) \mathrm{cm}^{-1} .{ }^{1} \mathrm{H}$ NMR (DMSO-d $\left.6,300 \mathrm{MHz}\right): \delta$ $(\mathrm{ppm})=3.92\left(\mathrm{~s}, 3-\mathrm{H}, \mathrm{OCH}_{3}\right), 7.03-8.04$ (m, 7H,Ar-H), 8.36 (s, 1H, 3-H), Mass, m/z; 389 (M+2). Elemental analysis (\%): Calcd, for $\mathrm{C}_{17} \mathrm{H}_{11} \mathrm{~N}_{2} \mathrm{O}_{2} \mathrm{SBr}$ : C; 52.73, H; 2.86, N; 7.23, S; 8.28 Found: C; 52.70, H; 2.85, N; 7.20,S; 8.25.

Ethyl 6-bromothieno[2,3-b]benzo[1,8]naphthyridine-2-carboxylate (4d). Yellow solid. Yield $82 \%$; mp. $245{ }^{0} \mathrm{C}$; FT-IR (KBr): $1685(\mathrm{C}=\mathrm{O}) \mathrm{cm}^{-1} .{ }^{1} \mathrm{H}$ NMR (DMSO-d $\left.6,300 \mathrm{MHz}\right): \delta(\mathrm{ppm})=$ $1.38\left(\mathrm{t}, 3 \mathrm{H},-\mathrm{CH}_{3}\right), 4.36(\mathrm{q}, 2 \mathrm{H}), 7.08-8.02(\mathrm{~m}, 7 \mathrm{H}, \mathrm{Ar}-\mathrm{H}), 8.20(\mathrm{~s}, 1 \mathrm{H}, 3-\mathrm{H})$, Mass, m/z; 403 
$(\mathrm{M}+2)$. Elemental analysis (\%): Calcd, for $\mathrm{C}_{18} \mathrm{H}_{13} \mathrm{~N}_{2} \mathrm{O}_{2} \mathrm{~S}: \mathrm{C} ; 53.88, \mathrm{H} ; 3.27, \mathrm{~N} ; 6.98, \mathrm{~S} ; 7.99$ Found: C; 53.85, H; 3.25, N; 6.95,S; 7.95 .

Methyl 6-methylthieno[2,3-b]benzo[1,8]naphthyridine-2-carboxylate (4e). Yellow solid. Yield $85 \%$; mp. $243{ }^{0} \mathrm{C}$; FT-IR (KBr): $1682(\mathrm{C}=\mathrm{O}) \mathrm{cm}^{-1} .{ }^{1} \mathrm{H}$ NMR (DMSO-d $6,300 \mathrm{MHz}$ ): $\delta$ $(\mathrm{ppm})=2.08\left(\mathrm{~s}, 3-\mathrm{H}, \mathrm{OCH}_{3}\right), 7.02-8.03(\mathrm{~m}, 7 \mathrm{H}, \mathrm{Ar}-\mathrm{H}), 8.22(\mathrm{~s}, 1 \mathrm{H}, 3-\mathrm{H})$, Mass, m/z; $324(\mathrm{M}+2)$. Elemental analysis (\%): Calcd, for $\mathrm{C}_{18} \mathrm{H}_{14} \mathrm{~N}_{2} \mathrm{O}_{2} \mathrm{~S}$ : C; 67.06, H; 4.38, N; 8.69, S; 9.95 Found: $\mathrm{C}$; 66.99, H; 4.34, N; 8.65,S; 9.91.

Ethyl 6-methylthieno[2,3-b]benzo[1,8]naphthyridine-2-carboxylate (4f). Yellow solid. Yield $76 \%$; mp. $230{ }^{0} \mathrm{C}$; FT-IR (KBr): $1680(\mathrm{C}=\mathrm{O}) \mathrm{cm}^{-1} .{ }^{1} \mathrm{H}$ NMR (DMSO-d $\left.6,300 \mathrm{MHz}\right): \delta(\mathrm{ppm})=$ 1.35 (t, 3H, - $\left.\mathrm{CH}_{3}\right) 2.09$ (s, 3-H, - $\left.\mathrm{CH}_{3}\right), 4.36$ (q,2H), 7.04-8.01 (m, 7H,Ar-H), 8.18 (s, 1H, 3-H), Mass, $\mathrm{m} / \mathrm{z} ; 336(\mathrm{M}+2)$. Elemental analysis (\%): Calcd, for $\mathrm{C}_{19} \mathrm{H}_{16} \mathrm{~N}_{2} \mathrm{O}_{2} \mathrm{~S}$ : C; 57.84, $\mathrm{H} ; 4.79, \mathrm{~N}$; 8.33, S; 9.53 Found: C; 57.81, H; 4.75, N; 8.30,S; 9.50.

Ethyl 6-methoxythieno[2,3-b]benzo[1,8]naphthyridine-2-carboxylate (4g). Yellow solid. Yield $79 \%$; mp. $224{ }^{0} \mathrm{C}$; FT-IR (KBr): $1690(\mathrm{C}=\mathrm{O}) \mathrm{cm}^{-1} .{ }^{1} \mathrm{H}$ NMR (DMSO-d 6 , $300 \mathrm{MHz}$ ): $\delta$ $(\mathrm{ppm})=1.37\left(\mathrm{t}, 3 \mathrm{H},-\mathrm{CH}_{3}\right) 3.95\left(\mathrm{~s}, 3-\mathrm{H}, \mathrm{OCH}_{3}\right), 4.38(\mathrm{q}, 2 \mathrm{H}), 7.00-8.03(\mathrm{~m}, 7 \mathrm{H}, \mathrm{Ar}-\mathrm{H}), 8.22$ (s, $1 \mathrm{H}, 3-\mathrm{H})$, Mass, $\mathrm{m} / \mathrm{z} ; 354(\mathrm{M}+2)$. Elemental analysis (\%): Calcd, for $\mathrm{C}_{19} \mathrm{H}_{16} \mathrm{~N}_{2} \mathrm{O}_{2} \mathrm{~S}: \mathrm{C} ; 57.84, \mathrm{H}$; 4.79, N; 8.33, S; 9.53 Found: C; 57.81, H; 4.75, N; 8.30,S; 9.50 .

\section{Spectral measurements}

Absorption spectroscopic measurements. Ultraviolet-visible absorption spectra were determined in a Perkin-Elmer model $554 \mathrm{UV}-\mathrm{Vis}$ recording spectrophotometer using quartz cuvettes of $10 \mathrm{~mm}$ light-path. The parameters of interaction between TBNC and calf thymus DNA were determined spectrophotometrically using a Beckman 25 double beam spectrophotometer. Aliquots of a concentrated DNA solution $(0.1 \mathrm{mM}-1.00 \mathrm{mM})$ were added to a cuvette filled with TBNC solution $(12-25 \mathrm{mM})$ and thoroughly mixed. Extreme care was taken to ensure that optical reference solutions were prepared in an identical manner.

Viscosity measurements. Viscosity measurements were made according to published procedures using a semimicro dilution capillary viscometer (Viscomatic Fica $\mathrm{MgW}$ ) with a thermostated bath $\mathrm{D} 40 \mathrm{~S}$ at $20{ }^{\circ} \mathrm{C}$. The flow time for water was $71.3 \mathrm{~s}$. For the viscosity experiments samples of calf thymus DNA were sonicated to fragments having an estimated molecular weight of approximately 500,000.

Thermal denaturation studies. The DNA melting studies were done by controlling the temperature of the sample cell with a Shimadzu circulating bath while monitoring the absorbance at $260 \mathrm{~nm}$. The temperature of the solution was continuously monitored with a thermo-couple attached to the sample holder. 


\section{Acknowledgements}

One of the author (R. K) thankful to Kuvempu University, Shankaraghatta, for awarding Research Fellowship and Director, SIF, IISc, Bangalore for ${ }^{1} \mathrm{H}$ NMR and mass spectra.

\section{References}

1. Noravyan, A. S.; ParonikyanVartanyan, E. G. S. A. Khim-Farm.Zh. 1985, 19, 790.

2. Litvinov, V. P.; Roman. S. V.; Dyachenko, V. D. Usp.Khim. 2000, 69, 218. [Engl.transl.Russ.Chem.Rev. 2000, 69, 201].

3. Chrzastek, L.; Sliwa, W. Aust. J. Chem. 1994, 47, 2129.

4. Barbara, B.; Teresa, Z. ARKIVOC 2001, (vi), 77.

5. Reissert, A. Berichte 1893, 26, 2137.

6. Koller, G. Berichite 1927, 60, 1918.

7. Via, L. D.; Uriarte, E.; Sanatna, L.; Marciani Magno, S. M.; Gia, O. ARKIVOC 2004 (v), 131 .

8. Zagotto, G.; Sissi, C.; Gatto, B.; Palumbo, M. ARKIVOC 2004 (v), 204.

9. Van der Plas, H. C.; Wozniak, H. J.; Van den Haak. Adv.Heterocycl.Chem. 1983, 33, 95.

10. Thummel, R. P.; Kohli, D. K. J. Heterocyclic Chem. 1977, 14, 685.

11. Gatto, B.; Capranico, G.; Palumbo, M. Curr. Pharmacol. Design. 1999, 5, 195.

12. Sainsburry, M. Synthesis. 1977, 7, 437.

13. Allard, B.; Jouini, M.; Bistocchi, G. A.; Orvietani, P. L.; Ricci, A.; Lescot, E.; Schwaller, A. J. Chem. Res. 1995, 1314.

14. Baez, A.; Gonzalez, F. A.; Vazquez, D.; Waring, M. Biochem. Pharmacol. 1983, 32, 2089.

15. Cao, Y.; He, W. X. Spectrochim. Acta. 1998, A54, 883.

16. Singh, M. P.; Joseph, T.; Kumar, S.; Lown, J. W. Chem. Res. Toxicol. 1992, 5, 597.

17. Tilak Raj, T.; Ambekar, S. Y. J. Chem. Res. 1988, 50, 537.

18. Nandeshwarappa, B. P.; Arun Kumar, D. B.; Bhojya Naik, H. S.; Mahadevan, K. M. J. Sulfur Chem. 2005, 26, 373.

19. Nandeshwarappa, B. P.; Arun Kumar, D. B.; Kumaraswamy, M. N.; Ravi Kumar, Y. S.; Bhojya Naik, H. S.; Mahadevan, K. M. Phosphorus Sulfur and Silicon Relat. Elem. 2006, 181, 1545.

20. Raghavendra, M.; Bhojya Naik, H. S.; Sherigara, B. S. J. Sulfur Chem. 2006, 27, 347.

21. Morimoto, Y.; Matusuda, F.; Shirahama, H. Synlett 1991, 202.

22. Markees, D. G.; Dewey, V. C.; Kidder, G. W. J. Med. Chem. 1970, 13, 324.

23. Jenekhe, S. A.; Lu, L.; Alam, M. M. Macromolecules 2001, 34, 7315.

24. Gia, O.; Mobilio, S.; Palumbo, M.; Pathak, M. A. Photochem. Photobiol. 1993, 57, 497.

25. Gia, O.; Conconi, M. T.; Uriarte, E. Farmaco 1997, 5, 289. 
26. Chilin, A.; Marzano, C.; Guiotto, A.; Manzini, P.; Baccichetti, F.; Carlassare, F.; Bordin, F. J. Med. Chem. 1999, 42, 2936.

27. Dalla Via, L.; Gia, O.; Marciani Magno, S.; Santana, L.; Teijera, M.; Uriarte E. $J$. Med.Chem. 1999, 42, 4405.

28. Dalla Via, L.; Uriarte, E.; Quezada, E.; Dolmella, A.; Ferlin, M. G.; Gia, O. J. Med. Chem. 2003, 46, 3800.

29. Scatchard, G. Ann. NY Acad. Sci. 1949, 51, 660.

30. Peacocke, A. R.; Skerrett, J. N. H. Trans. Faraday Soc. 1956, 52, 261.

31. Blake, A.; Peacocke, A. R. Biopolymers 1968, 6, 1225.

32. 32.Wakelin, L. P. G.; Ramonas, M.; Chen, T. K.; Glaubiger, D.; Canellakis, E. S.; Waring, M. J. Biochemistry 1978, 17, 5057.

33. Cohen, G.; Eisenberg, H.; Biopolymers 1969, 8, 45.

34. Crothers, D. M.; Zimm, B. H. J. Mol. Biol. 1965, 12, 525.

35. Long, E. C.; Barton, J. K. Acc. Chem. Res. 1990, 23, 271.

36. Mee, S. L.; Pierre, A.; Markovits, J.; Atassi, G.; Sablon, A, J.; Saucier, J. M. Mol. Pharmacol. 1998, 53, 213.

37. Patel, D. J.; Acc. Chem. Res. 1979, 12, 118. 